\title{
POLICY OF TIME ECONOMIC RECOVERY COVID-19 PANDEMIC IN INDONESIA YEAR 2020-2021
}

\author{
By : \\ Endang Naryono \\ LECTURER OF STIE PASIM SUKABUMI \\ rtumarima@gmail.com
}

\begin{abstract}
ION
The COVID-19 pandemic for almost two years has had a very extraordinary and frightening impact, there have been 2.3 million cases of covid-19 with a cure rate of $84 \%$ and a death rate of $2.6 \%$ in July 2021 . The Covid-19 pandemic has not only created a humanitarian disaster but has an impact National economic downturn, such as negative economic growth, declining purchasing power, increasing poverty and uncontrolled unemployment. The government's policy by carrying out a two-legged policy, the first is to break the chain of the spread of this pandemic with regulations and health protocol policies. The second is economic recovery during the pandemic with social assistance to the community, SMEs and industrialization so that they still have purchasing power to move the real sector. Inaccurate data, limited infrastructure and budget constraints are the biggest obstacles to economic recovery during the pandemic. UKMM is the final foundation and backbone of the national economy in the midst of an economic recession in its second year.
\end{abstract}

Keywords: economic recovery during the pandemic

\section{PRELIMINARY}

The Corona virus or known as Covid-19 started at the end of 2019 in Wuhan, China within 2 years and quickly spread throughout the world and destroyed the life of the nation and state by affecting all aspects of life from health, politics, security and economy. Almost the whole world has felt the impact of the spread of Covid-19 and it has had a tremendous impact on the human social fabric, tens of millions of people have been exposed to this Covid-19 with the death toll reaching millions. In addition to health and safety, which are threatened by COVID-19, this has an impact on the world economy, namely the decline in economic growth due to the cessation of the production sector and the decline in people's purchasing power. One of the countries affected by this covid-19 is Indonesia, in early March the confirmation of this covid-19 quickly spread throughout Indonesia and in June 2021 the positive number of covid-19 had reached 2.1 million people with a death rate of $2.7 \%$ which is one of the causes of death. This country has the highest death rate due to COVID-19.

As a result of Covid-19 having a very bad impact on the national economy, economic growth from 2020 to June 
2021 is a minus, the post-budget is disrupted due to the budget allocation focusing on handling Covid-19, almost 700 trillion of the budget has been used to deal with COVID-19 with an increasingly budget deficit. widened by a thousand trillion, greater than the set at 3.5 of GDP, the unemployment rate increased as the production sector stopped, poverty increased due to the decline in people's purchasing power, and crime increased due to the correlation of rising unemployment and poverty in the country, which nationally entered into an economic recession. which has an impact on the multidimensional order of the life of the nation and state.

In dealing with the economic impact caused by COVID-19, the government as the policy holder carries out policies in the economic field with the main objective of the real economic sector moving people, people have purchasing power and still create jobs for the community. Starting from short-term and long-term programs from macro policies to micro policies. It's just that the economic policies carried out are still temporary and seem sporadic without being studied more deeply the causes and consequences of these policies such as pre-employment cards by providing assistance to people who have not worked on the condition that they attend training, namely people buy training online for 3 times and then get a certificate of expertise. Of course, it is very unlikely that 3 meetings can produce good hard skills because the results will always correlate with the process. Social assistance to workers whose salaries are below 4 million, social assistance to lecturers, teachers and education staff, free assistance for $450 \mathrm{~V}$ voltage electricity bills, quota assistance for students, teachers, students and lecturers and many other economic programs during this pandemic The main objective of this policy is to maintain people's purchasing power and the community can withstand the storm of the COVID-19 pandemic which has an impact on a deep economic recession.

The policy of increasing MSME liquidity, namely for small, medium and micro entrepreneurs by distributing financial assistance, the community is very enthusiastic about registering for this assistance, it's just that the effectiveness of this program for two years has not been able to show the impact of positive changes and the economic situation is getting worse leading to a deep economic recession. . This is due to poor planning and poor distribution of information channels, plus the data bank owned by the government for each department has different data and is not even synchronized, then programs that are not well targeted, many people get assistance even though they should not get it. , there are many who should get but they do not get not to mention the many leakages of this economic policy which resulted in huge losses for the country.

From the description that has been conveyed regarding the government's policy in economic recovery due to COVID-19, which is a very limited budget dilemma and is sucked in by the handling of Covid-19, on the one hand, the micro economy still has to move so that people have purchasing power and do not fall into poverty, but this policy 
has not yet been implemented. certainly succeeded because it was not carried out in depth and temporally unsustainable, not to mention the leakage of the aid budget which resulted in losses for the state. So in this study to find out how big the impact of economic recovery policies during the pandemic in Indonesia.

\section{ECONOMIC RECOVERY POLICY}

\section{Economic Glorification and Social Protection}

The realization of the National Economic Recovery (PEN) program in 2020 has reached Rp366.86 trillion or $52.8 \%$ of the total budget prepared by the government of Rp695.2 trillion. The PEN Task Force hopes to maximize the distribution of the PEN Program in the fourth quarter of 2020 to support the community's economic movement and as a lever for economic growth.

The largest distribution of the PEN program came from for Social Protection which had a budget allocation of Rp. 203.9 Trillion and Rp. 176.38 Trillion has been realized or distributed $86.51 \%$ of the total budget. So far, social protection programs have been getting better and better. Programs that are included in the social protection cluster include PKH (Family Hope Program), Sembako Card/BPNT (Non-Cash Food Assistance), Non-Jabodetabek Cash Assistance, Jabodetabek Food Assistance Social Assistance, Logistics/ Food/ Basic Food, BLT (Direct Cash Assistance ) Village Funds, and Electricity Discounts. It's just that many problems that often occur are the unsynchronization of primary data at the village, sub-district and central levels so that there are still many who don't get it even though they deserve it.

The Social Protection Cluster which is under the Ministry of Social Affairs program has a budget allocation of Rp128.9 Trillion. This budget has been absorbed by Rp112.7 trillion (87.44\%). The rest is scheduled for disbursement until the end of 2020, quantitative budget absorption is indeed high, but quality is still in doubt, despite data that is not synchronized and updated, there are still many wastes that have the potential to harm state finances.

Social protection programs that have been started since March 2020 are regular programs that are expanded, such as PKH and BPNT. Meanwhile, new programs that are specific in nature to deal with COVID-19 have also been implemented quite well by carrying out good cooperation between institutions and local governments which include sub-districts, sub-districts, districts/cities, provinces and the central government.

PKH distribution which has reached 10 million Beneficiary Families (KPM). Then the Sembako Program or BPNT which previously had a target of 15.2 million KPM was expanded to 20 million KPM and the target is targeted for completion in September 2020. A special program to deal with COVID-19 is in the form of Social Assistance for the Jabodetabek Basic Food with a target recipient of 1.9 million KPM and The Jabodetabek Cash Assistance (BST) with a target of 9 million KPM recipients has reached the target. Two other additional programs in collaboration with BULOG, namely the Rice Assistance for KPM PKH with a target 
of 10 million KPM, have started in August and will be completed in November 2020, with a total distribution of 450 thousand tons of rice. One more BST for the non-PKH Basic Food Program KPM with a target of 9 million KPM which has been implemented in September 2020.

The $\mathrm{PKH}$ assistance program from a budget of Rp. 36.71 trillion has been absorbed by reports of $100 \%$. For BPNT, from a budget of Rp. 43.12 Trillion, Rp. 37.31 Trillion has been absorbed, and the rest will be disbursed until the end of 2020. In terms of budget for special programs, the first is the Jabodetabek Sembako Social Assistance, this will be completed in December which is currently being realized. amounting to Rp5.65 trillion from the Rp6.84 trillion budget. Then the Cash Social Assistance has been running until December 2020 with the realization of $\mathrm{Rp}$. 25.86 Trillion from the Rp. 32.4 Trillion budget. The last one is the Cash Social Assistance for Non-PKH Basic Food KPM which has been fully executed in September 2020 with a budget of IDR 4.5 Trillion.

Several programs are currently underway starting in January 2021, both regular ones such as the PKH and BPNT programs which will be held from January 2021, as well as the BST program which will be held from January - June 2021. The social protection cluster in the PEN program is to immediately rearrange plans distribution program in the first quarter of 2021. This is to maintain national consumption and is expected to contribute to economic recovery which is currently still slumped with negative economic growth rates. Communities who receive assistance must be those who feel the greatest impact and are at the bottom of the class and must be assisted. Absorption until December 2020 until next year, the focus is that social protection programs, whether in the Ministry of Social Affairs, the Ministry of Manpower, or other Ministries and Institutions, will be encouraged because they have the greatest impact on the poorest people.

The second focus of the PEN program is to pursue the absorption of assistance for MSMEs, because more than $90 \%$ of MSMEs absorb labor and contribute more than $50 \%$ of the National GDP. Ending in the fourth quarter of 2020. The rest of the PEN budget as a whole is IDR 170-180 trillion. At least pursue the absorption of Rp. 100 trillion until December, and if you can absorb all of it, it will have a positive correlation to increase people's purchasing power and the national economy on the condition that the programs implemented can really benefit the people who are affected by this pandemic.

The Presidential Assistance Program (Banpres) for Productive Micro Enterprises (BPUM) worth Rp. 2.4 million for MSME actors gave positive results to maintain and even develop the businesses of the perpetrators. The program, which was launched in August 2020, has been $100 \%$ disbursed in October 2020 to 9 million target beneficiaries, namely, microentrepreneurs whose main role has not been touched by banking services. This program is quickly absorbed with the support of the Himbara Bank, Cooperatives, local governments, and Ministries/Agencies that provide assistance. The government will increase the number of micro-entrepreneurs who 
are beneficiaries of the BPUM to a total of 12 million MSMEs.

Micro, Small and Medium Enterprises (MSMEs) are the backbone of the Indonesian economy. Apart from being a source of national economic dynamics, MSMEs also absorb the national workforce. During the Covid-19 pandemic, Indonesian MSMEs have been able to survive and quickly adapt to difficult conditions. At the time of the PSBB, $50 \%$ of our MSMEs were still running normally. After several months of relaxation, $50 \%$ of which was running normally began to feel the effects, now only $63 \%$ are operating on a limited basis. Meanwhile, what was previously operating on a limited basis that returned to normal was very small, only $1 \%$. So nationally, UKMM assistance must be maintained and budgeted periodically, not temporally because it has a positive correlation for the national economy.

One of the driving forces for the revival of Indonesian MSMEs in the economic conditions of the Covid-19 pandemic are the National Economic Recovery (PEN) programs. Cumulatively, the four program clusters that have become the focus of the PEN Task Force are the social protection sector, MSMEs, Ministries/Agencies and Local Governments (K/L/D), as well as corporate financing which reached a realization of IDR 277.68 trillion in the first week of the fourth quarter of 2020 . Absorption Significantly occurred in the MSME sector, namely the Productive Presidential Assistance Program (Banpres) for Micro Business. has been absorbed maximally for the initial stage for 9.1 million micro-enterprises. This program provides grants of Rp. 2.4 million to micro and small business actors. The weakness in this program is that the data held is still not valid so that the data owned is the result of the UKMM registering not the data owned by the government and then distributed to those who are entitled to it so that very many UKMMs have just emerged when they know about social assistance for UKM so that it will reduce the effectiveness of the program and even miss the target. The government has disbursed Banpres Productive assistance, it is the right step and at the same time improving the demand side and also maintaining purchasing power, because it also determines business prospects in the medium and long term.

The PEN program run by the government is quite right on target, it is shown that the majority of recipients of credit restructuring are indeed businesses whose turnover has decreased by $50 \%$. Then businesses that receive interest subsidies are businesses with stable turnover or even developing during a pandemic due to changes in people's behavior patterns in purchasing decisions.

In terms of program diversification between credit restructuring and interest subsidies. It is appropriate for credit restructuring to focus on affected MSMEs and indeed need working capital, on the other hand, which need expansion through the interest subsidy program. The positive aspect of government support for MSMEs is that previously, the majority of MSMEs only had less than three months of working capital, now with the PEN program, they can increase their working capital for more than four months. Where $79 \%$ of MSMEs are aware of the PEN program, through communications made by the 
Government. $83 \%$ of MSMEs think that this program is very helpful to maintain their business.

\section{Economic Growth With Consumption}

Efforts to restore the national economy that were affected by the COVID-19 pandemic in 2020 continue to be pursued to date amid the rising positive number of COVID-19. In addition to the National Economic Recovery (PEN) programs, the government sees the need to encourage public consumption so that the national industrial sector continues to move so that jobs are created again. From the demand side, household consumption is still the highest contributing $57.6 \%$ of Gross Domestic Product (GDP), the second is PMTB (investment) $31.6 \%$, meaning to pursue economic growth and focus on household consumption and investment.

The key driver for economic growth in 2021 is, of course, encouraging household consumption, how do we increase the purchasing power of the lower-middle class economy by rolling out social security network programs, and building the confidence of the uppermiddle economic community to increase people's purchasing power again. 2021 is a momentum to encourage investment. Several Indonesian macroeconomic indicators show some positive signals. Almost all commodities have improved, several industries have started to move, imports of raw materials and capital goods entered the fourth quarter of 2020 , the trend began to increase and there was a balance of payments surplus during this pandemic.

So we hope this is an indication that the real sector is starting to move. Some commodities, especially palm oil and some mining products in the international market are priced quite well, so that exports are quite strong. If it is concluded, in 2021 the economy will be better provided that the handling of the covid-19 pandemic is successful but otherwise it will create a time bomb that will explode and cause terrible losses.

On the supply side, there were indeed many sectors that were hit, for example, the manufacturing sector contributed $19.8 \%$ to the industry, so focus on this industry because the multiply effect will be enormous, related to employment. The government also launched a package of relaxation policies for the Sales Tax on Luxury Goods (PPnBM) to encourage the automotive industry. Apart from the fact that this industry is deeply affected, on the other hand, the multiply effect of this industry is quite large because the supporting sectors are also quite large. It is hoped that this policy will reduce the price of motorized vehicles, and increase the purchase of motorized vehicles. The scheme is the provision of Governmentborne PPnBM fiscal incentives targeted to take effect March 1, 2021 to encourage economic growth in the first quarter of 2021.

This program will utilize the purchasing power of the existing community, in order to encourage demand (demand). This policy is quite appropriate if it targets the middle to upper economic community group. If we restore the purchasing power of the people or the class of society, the effect will be very large for demand growth, PPnBM is planned to be carried out in stages and the regulations must be revised and evaluated every three months. In addition, the PPnBM policy is also planned to run with other fiscal policies 
in the 2020/2021 fiscal year because this program is temporary in nature so that if it is continued in the medium term it will reduce state revenue from taxes.

OJK and BI must look at the scheme for buying motor vehicles in the community, mostly through credit. so that several other policies must accompany this PPnBM policy. This is because one another is interrelated and has interests. The goal is to increase consumption, and the choice to encourage automotive purchases has a very large impact from upstream to downstream. This helps the auto industry to be able to survive until the pandemic ends. Of course, with a note that later this policy can be expanded, not only targeting the middle to lower economic group. Overall, this policy is quite good because with the consumption growth again it will move the industry so that it will generate employment again, and reduce the unemployment rate.

The Committee for Handling COVID-19 and National Economic Recovery (KPCPEN) was formed in the context of accelerating the handling of COVID-19 as well as economic recovery and national economic transformation. KPCPEN's priorities in order are: Healthy Indonesia, realizing safe people from COVID-19 and reforming health services; Indonesia Works, realizing empowerment and acceleration of labor absorption; and Indonesia Grows, realizing the recovery and transformation of the national economy. In its implementation, KPCPEN is assisted by the COVID-19 Handling Task Force and the National Economic Recovery and Transformation Task Force.

\section{National Economic Awakening}

Various economic policies will be carried out by the government in 2021 . The Ministry of Finance allocated funds for the 2021 National Economic Recovery (PEN) of Rp 699.43 trillion. This fund increased from the previous allocation of Rp. 695.2 trillion, an increase of $20.63 \%$ from the realization of the 2020 PEN budget. This budget increase is expected to maintain the momentum of the national economic recovery, especially to encourage economic growth in the first quarter of 2021. sectors namely, health of $\mathrm{Rp}$. 176.3 trillion, social protection of $\mathrm{Rp}$. 157.4 trillion, MSME support and corporate financing of Rp. 186.8 trillion, business and tax incentives of Rp. 53.9 trillion, and priority programs of $\mathrm{Rp}$. 125.1 trillion. Looking at the economic growth of 2020 ago, national economic growth still has resilience, because the government carried out several economic policies that were fast and measurable and more than usual. It is seen that there is flexibility in the APBN to reallocate and refocus.

With this policy, the trend of Indonesia's economic growth has improved since the second quarter of 2020, although it is very concerning at the minus position. It is expected to increase in the first quarter of 2021. Therefore, the state budget remains countercyclical and the vaccination program is expected to be effective so that economic recovery can be strengthened. In general, PEN is quite optimal in boosting the economy. Social protection programs help people's purchasing power in the midst of a pandemic. The coverage of social protection and targeting is getting better. The survey results for MSMEs show that 
this intervention made the majority of MSMEs able to survive.

For the 2021 fiscal year, the government plans to strengthen measures to overcome the pandemic and economic recovery, "So the priority policies are for vaccination, strengthening $3 \mathrm{M}$ and $3 \mathrm{~T}$, including PPKM Micro, as well as the PEN program, with the hope that the economy will move in 2021 at $4.5 \%$ growth. -5.3. In fact, what is being faced is not an economic problem but a pandemic problem. The national economy is affected by the pandemic. We must believe that we can overcome this pandemic so that the national economy will grow positively.

The economic recovery is indeed on the right track and has shown improvement, BPS data shows that almost all business sectors are starting to improve. Even so, the effectiveness of the PEN program does not directly restore the national economy, but it is intended first to overcome the pandemic, secondly to help the community and the business world so that when the pandemic subsides our economy is ready to rise. The government must remain focused on tackling the pandemic, then increasing the speed and accuracy of assistance to affected communities, including increasing assistance to the business world, as well as accelerating the implementation of the Job Creation Law, because one of the conditions for us to recover is through the investment we have prepared in the law. That

\section{National Tourism Innovation And Differentiation}

During the COVID-19 pandemic, tourism has been one of the sectors that has been severely affected. Especially with the restrictions on various activities and community mobility in order to cut off the transmission of COVID-19 transmission. A year into the pandemic, tourism in Indonesia is gradually rising with various adaptations. With the COVID-19 vaccination, the revival of the Indonesian tourism sector can accelerate. Tourism is one of the priority sectors because it contributes employment to 34 million people throughout Indonesia. Vaccination for tourism sector actors and the creative economy is a colossal step for the revival of tourism and the creative economy. "This measure starts in Bali on February 27-28. This is a form of rapid movement and collaboration between the government, the business world, and the community.

The prediction for 2021 shows a positive trend. "The consensus of analysts is that in 2021 Indonesia will rise. The World Bank predicts that the Indonesian economy will be positive 3.1 percent in 2021. In fact, the IMF estimates that the economy will grow 4.8 percent this year and 6 percent in 2022. To prepare for the rise of tourism, prepare three steps, namely product innovation and tourist destinations according to trends. Then adaptation and collaboration. "Focus on the domestic segment first. Adaptation by staying disciplined with 3M's health protocols by encouraging CHSE (clean, health, safety, and environmental sustainability) certified destinations.

The pandemic has changed the trend of tourism from mass tourism to sustainable tourism. Travel preferences are customized, personalized, localized, and smaller in size to reduce transit and contactlessness. Now what is being sought is open-air culture-based tourism. 
Nature and culture. from just looking at the white sandy sea of sunshine now looking for silence, sustainability, spirituality from his visit to tourism places. Another program that has been prepared is a destination based on the free covid corridor, where destinations in the green zone are starting to open for foreign tourism.

The impact of the pandemic has been felt on tourism and the economy. "The hotel is empty, the restaurant is quiet. For the first time in history, economic growth in Bali experienced the deepest contraction to reach 12 percent. The worst record so far is in Bali and the lowest nationally in 2020. So the COVID-19 vaccination program must be welcomed for these tourism actors. To revive Bali's tourism, there is no choice but to control the pandemic first and make it a green zone area. One of them is that Bali has prepared two areas for the implementation of the free covid corridor, namely in Nusa Dua and Ubud.

In order to immediately revive tourism in Bali in particular and Indonesia in general, it is necessary to work together and not to work alone. All can contribute with their respective expertise in order to solve the global pandemic problem. Vaccination in the tourism sector that takes place in Bali is a form of collaboration from various parties. The central government through the Ministry of Health and the Ministry of tourism and creative economy is working with the Bali Provincial Government and its staff and the private sector, namely Grab Indonesia. To move quickly with a wide reach requires innovation and technology.
There are three things that are done in the vaccination of public servants in the tourism sector in Bali. "The first is the drive thru innovation which is the first in Southeast Asia. Then achieve operational excellence through a technology approach. Because it has to be fast and a lot, it is necessary to optimize the process according to standards. In addition, embracing the community for a wider reach.

The revival of tourism is a signal of Indonesia's revival. Vaccination is one of several pillars of handling COVID-19. Even though vaccination has started, you must still be disciplined in implementing the $3 \mathrm{M}$ and $3 \mathrm{~T}$ health protocols. Indonesia must survive, take opportunities, and win from the COVID19 pandemic by continuously adapting to implementing health protocols in a disciplined manner.

\section{Vaccination is an Absolute Requirement for Economic Recovery}

In the past year, the Indonesian economy has contracted due to the COVID-19 virus, which spreads very quickly and causes illness and death. The prolonged pandemic has also had a major impact on the economic sector. The vaccination program launched this year is expected to be able to bring the Indonesian economy back to 5 percent growth due to the impact of the pandemic. In general, scientific studies show that a one-dollar vaccine investment can yield an economic return of eight dollars. Let's say we spend IDR 100 trillion for vaccines this year, but once our economy grows with a projection of $5 \%$, it will have a tremendous impact on the national economy. 
All stakeholders, national and local leaders alike, are fighting for vaccination as one of the most effective, efficient, and fastest ways to restore personal health and at the same time drive the economy in the future. A small part of the community still does not understand the benefits of vaccines for this common interest. The best way to provide awareness and calm to these public doubts is by direct example by community leaders and leaders. the community needs to be given a better communication approach in order to understand that the interests of this vaccination program are common interests and have a broad impact on the national economy.

The government must be able to carry out a massive COVID-19 vaccination program targeting 181 million Indonesians. Vaccination is not a new thing for Indonesia, we have been doing it since 50 years ago, starting from smallpox vaccination, polio, BCG, and so on. Availability of vaccines, in conditions of a global pandemic like this, the COVID-19 vaccine has become a bone of contention for other countries, so the ease of access to the COVID-19 vaccine needs to be controlled. "Therefore, there is a need for vaccine cooperation through the COVAX organization which together ensures that less fortunate countries still have access to vaccines, Bio Farma and is committed to COVAX. But again, the supply of vaccines is the key to the speed of the vaccination program.

The government's efforts to bring in vaccines, both through bilateral and multilateral cooperation, have so far been quite successful. To date, Indonesia has 40 million stocks of COVID-19 vaccines and hundreds of millions of doses are scheduled to be delivered until the end of 2021.

\section{Economic Recovery Due to the National Covid-19 Pandemic}

Besides handling health during the Covid-19 pandemic in 2020, the government also continues to try to restore the economic sector affected by the pandemic, these two things are the main focus and must be carried out carefully during the Covid-19 pandemic.

The principle that has always been held by the government is that the opening of the economic sector in the midst of the Covid-19 pandemic is always guided by health protocols and other related provisions aimed at preventing transmission. Through the National Economic Recovery (PEN) program, the government focuses on helping the economic sector to survive and recover during the Covid-19 pandemic. The realization of PEN distribution as of December 23, 2020, has reached Rp502.71 trillion or $72.3 \%$ of the total budget of Rp695.2 trillion. In addition to being aimed at recovering the economic sector, the budget allocation is also focused on social assistance programs (bansos) provided to communities affected by the Covid-19 pandemic.

During the pandemic, the government must be careful in formulating policies, including the opening of the social and economic sectors. Because on the one hand the government wants to protect the community from contagion, while on the other hand the two sectors that support public welfare cannot be totally paralyzed. Therefore, in making decisions, the government is very careful based on the magnitude of the risk of 
contagion and the magnitude of its impact on the economic sector. Where in principle, the regulation of restrictions on socio-economic activities aims at common safety and health.

For this reason, in accelerating the handling of the Covid-19 pandemic and economic recovery in Indonesia, as of July 20, 2020, the government decided to change the organizational structure related to Covid-19. What was originally carried out by the Covid-19 Task Force changed its name to the Covid-19 Handling Task Force which specifically handles the Covid-19 pandemic, and the National Economic Recovery Task Force (PEN) which focuses on restoring the economic sector due to the pandemic.

The two task forces are under the Covid19 Handling Committee and National Economic Recovery (KPCPEN). This change in organizational structure is a very important milestone, to ensure that all programs that have been determined can be coordinated, executed properly, and also evaluated properly so that the handling of the pandemic and the national economic recovery can run effectively and on target.

All efforts to handle the Covid-19 pandemic and the recovery of the national economy should be a golden capital for learning for the Indonesian people. This learning is in terms of facing challenges, especially infectious disease outbreaks that have the potential to occur in the future and be experienced by the next generation.

\section{UKMM Digital Economy During the Pandemic}

The government and various stakeholders work hand in hand to overcome the challenges that arise due to the COVID-19 pandemic. In addition to trying to suppress the rate of positive cases of COVID-19, the government is also trying to restore the national economy through various programs. The government allocates a budget of IDR 695.2 trillion for the economy and health. One of the highest budget allocations is to support micro, small and medium enterprises (MSMEs), amounting to Rp123.46 trillion in the form of interest subsidy programs, credit guarantees, tax relaxation, and productive assistance. The government also provides assistance for business management, human resources, infrastructure, including facilitating the digitization of MSMEs. The digitization of MSMEs is basically the government's big agenda to restore and transform the digital economy.

For conventional MSMEs who have been transacting more traditionally, face to face with both consumers and raw material providers, digitalization will be very helpful during this pandemic. "Now one way to survive during a pandemic is digitization. By transforming digitally, relationships with consumers and with raw material providers can be carried out. Efforts to digitize the business processes of MSME actors, especially those who are still unfamiliar with technological developments, are still difficult because of the mindset of the perpetrators themselves, but they still have to provide assistance. Mentoring takes various forms, it can be through training, coaching, gathering, and consultation. The point is that MSMEs must prepare themselves towards digitalization. 
All aspects are transforming towards digitalization to respond to the changing landscape due to the COVID-19 pandemic. Digitalization support, especially in food stalls, has a positive impact on business people. The support we provide we call P3K (Training, Guidance, Income, and Ease). This is what raises the degree of our MSME actors, especially food stall owners. The presence of the application helps transform MSMEs towards digital business processes, the community must be helped to advance to class by digitizing in any way. Starting from the digitization of books, from there we can see their cashflow, we can know what their needs are.

This journey towards digital business processes brings change. With digital, new opportunities will also emerge. This new opportunity will have a big effect on the economy. The term is that in this change, there must be a loser and a gainer. The presence of the National Economic Recovery (PEN) program is a form of state presence for MSME actors. at the Micro level who have not been touched by banking services, or do not yet have a NPWP, so that special handling is needed such as Micro Business Productive Assistance (BPUM), this is what helps Micro businesses which previously declined to at least return to their original point.The key now is to immediately change in terms of innovation, so that MSMEs can raise their class.

Currently with the changing situation, MSMEs must be able to adapt, one way is by digitizing and preparing themselves to enter a new world. Digital is not just entering, but preparing for change and its consequences later. Experience in various economic crises has taught Indonesia that micro, small and medium enterprises (MSMEs) act as the backbone and buffer that saves Indonesia from various economic problems. The side that is now being highlighted to support MSMEs, especially during the COVID-19 pandemic is the acceleration of digital transformation. One of the programs carried out by the Ministry of Cooperatives and Small and Medium Enterprises (Kemenkop UKM) is to invite young innovators to support the digitization of MSMEs through the MSME Digital Hero program.

In this difficult situation, many MSMEs are able to survive and even increase their sales because they are connected to the digital ecosystem. However, only 1011 million MSMEs are connected to the digital ecosystem. At the same time, I saw a lot of young people who came up with innovations to help MSMEs to go digital. The digital innovations and services presented by these UMKM Digital Heroes are indeed able to solve local problems in the field. Based on BPS data as of September 2020, the conditions faced by MSMEs are indeed quite challenging. "That $45 \%$ of SMEs are only able to survive for 3 months in economic conditions during a pandemic like this. Asian Development Bank (ADB) survey data related to the impact of the pandemic on MSMEs in Indonesia, $88 \%$ of micro businesses run out of cash or savings, and more than $60 \%$ of these micro and small businesses have reduced their workforce. Therefore, it is very important for micro-enterprises to intervene with financial literacy," said Fiki Satari, Special Staff of the Minister of Cooperatives and SMEs. 
The Ministry of SME Cooperatives itself has a strategy for developing the digitization of SMEs in 4 stages. The first is to increase Human Resources by preparing MSME business actors so that their capacity can be increased. The second is to intervene in the improvement of its business processes which are lowered into several programs. The third is the expansion of market access, one of which is the Kemenkop UKM in collaboration with the Government Goods/Services Procurement Policy Institute (LKPP) so that UMKM players can become vendors for the procurement of government goods and services. Fourth is to glorify local heroes of SMEs.

The conditions for these MSME actors are that they are lighter, empowered, have a strong brand, and overall are able to aggregate Micro and Small businesses to anchor to digital platforms or to international markets (exports) later. The challenges of MSMEs in Indonesia are indeed quite diverse and it is necessary to find appropriate solutions, because they are related to the entrepreneurship ratio in Indonesia which has only reached $3.5 \%$. This condition is considered necessary to create conditions of ease of doing business in order to increase the ratio. MSMEs also need to be directly connected to the industrial supply chain, whose access has now only reached 15\%," added Fiki Satari.

One of the innovators of MSME Digital Heroes is Credibook, a digital service engaged in financial records. "This creditbook is entered through a financial recording service that focuses on solving the cash payment problem (debts) that is often felt by MSME entrepreneurs. This product derivative is moving towards digital payments, especially on the bill payment side. also collaborates with several institutions to help MSMEs increase their capital financing," said Gabriel Frans, Co-Founder and CEO of Credibook.

The potential of Indonesian MSMEs is so great that it inspires them to get involved further. While the digitization of MSMEs is still few, for example, wartels have now been replaced by cellphones, and letters have changed to email. Financial records will definitely be replaced, it's just a matter of momentum and who wants to do it. We at Credibook, decided not to just be spectators but to participate in the digitization of MSMEs.

From the digital economy projections compiled by Google and Temasek Holding, Indonesia's largest digital economy sector in Southeast Asia, with economic potential until 2025 will reach almost Rp. 2000 trillion. Seeing such great potential, the government and all stakeholders should work together to encourage this economic potential to reach its optimal point.

\section{BIBLIOGRAPHY}

https://covid19.go.id/

https://www.kemenkeu.go.id/

https://kemensos.go.id/

https://kemnaker.go.id/

https://kemenparekraf.go.id/

https://www.bi.go.id/id/default.aspx

https://www.bps.go.id/ 